I N V I T E D P A P E R*

\title{
FROM CUBA TO MOST OF THE NEOTROPIC: HABENARIA BICORNIS (ORCHIDACEAE) IS WIDESPREAD FROM MEXICO TO SOUTHEASTERN BRAZIL
}

\author{
João A. N. Batista ${ }^{1,3}$, Karina Proite $^{1}$, Bruno M. Carvalho ${ }^{1}$, Aline A. Vale ${ }^{1}$ \\ \& LeONARDo P. FELIX ${ }^{2}$
}

\begin{abstract}
${ }^{1}$ Departamento de Botânica, Instituto de Ciências Biológicas, Universidade Federal de Minas Gerais, Av. Antônio Carlos 6627, Pampulha, Belo Horizonte, Minas Gerais 31270-910, Brazil

${ }^{2}$ Departamento de Ciências Biológicas, Centro de Ciências Agrárias, Universidade Federal da Paraíba, Campus II, Areia, Paraíba 58397-000, Brazil

${ }^{5}$ Author for correspondence: janb@icb.ufmg.br
\end{abstract}

\begin{abstract}
Habenaria bicornis was first described in 1835 from Cuba and has only been known from that country and from a few records in Panama from the 1920s. Here we show that H. bicornis and H. goyazensis, known from Brazil and Guyana, are conspecific and that the species is distributed from Mexico to southeastern Brazil. Niche modeling and collection data indicate that this species has a preference for wet lowland savannas and its distribution is predicted to include most of the Neotropics with suitable habitats. The molecular phylogenetic analyses based on DNA sequences from the nuclear internal transcribed spacer (ITS) region and part of the plastid $m a t K$ gene placed $H$. bicornis in an isolated position near the base of the Neotropical clade, although with low support. In terms of its morphology, its relationships are likewise not clear as there are no evident similarities between H. bicornis and the basal subclades or any other Neotropical subclade. Cytogenetic analysis indicated a basic chromosome number of $x=21$, similar to other basal Neotropical species.
\end{abstract}

Resumen: Habenaria bicornis fue descrita por primera vez en 1835, para Cuba, y era conocida apenas para este país y unos pocos registros de Panamá, de 1920. En el presente estudio, demostramos que H. bicornis y H. goyazensis, esta última conocida para Brasil y Guiana, son específicas y la especie se distribuye desde México hasta el sudeste de Brasil. El modelado de nicho y la recolección de datos indican que esta especie posee una preferencia por sabanas húmedas de tierras bajas y es predicho que su distribución incluye gran parte del Neotrópico con hábitats favorables. Los análisis filogenéticos moleculares con secuencias del ADN nuclear (ITS) y plastidial (matK) ubicaron H. bicornis en una posición aislada próximo a la base del clado Neotropical, aunque con bajo soporte. En términos de su morfología, sus relaciones no están aclaradas, ya que no hay similitudes evidentes entre H. bicornis y los subclados básales o cualquier otro subclado Neotropical. Los análisis citogenéticos indican un número cromosómico básico de $x=21$, similar a las otras especies basales del Neotrópico.

KEY WORDS: Biogeography, cytogenetics, molecular phylogenetics, Orchidinae, taxonomy

Habenaria Willd. (Orchidinae, Orchideae, 2001). In a synopsis of the New World species of the Orchidaceae) is a large genus of terrestrial orchids genus, Batista et al. (2011a) listed 298 taxa for the comprising approximately 881 species (Govaerts et al. Neotropics. Brazil, with 163 taxa, and Mexico, with 2013) distributed throughout tropical and subtropical 79 species, are the major centers of diversity of this regions of the Old and New Worlds (Pridgeon et al. genus in the New World. Although some species are

* This contribution was prepared as part of the special edition of LANKESTERIANA that is dedicated to the commemoration of Lankester Botanical Garden's 40th anniversary. 
widely distributed throughout the American tropics and subtropics, most (69\%) are restricted to a single country. Narrow endemics are few, however, and in many cases endemic taxa can represent obscure taxa or species known from a few collections or just the type material, so that their exact identity often remains unclear.

Studies of New World Habenaria and New World Orchidaceae have generally been undertaken on a piecemeal basis, and limited by geographic and political subdivisions. Floras have been published for several countries, but revisions on continental scales are few and have largely been limited to groups with small numbers of species. As a consequence, several species (especially those with broad distributions) have been described several times from different countries. An example of this situation is H. trifida Kunth, which is currently known from Mexico to northern Argentina but first described from Colombia and only later from Brazil, Venezuela, Mexico, Paraguay, and Costa Rica - and now comprises 21 synonyms (Batista et al. 2011b).

Habenaria bicornis Lindl. was described by Lindley (1835) based on a collection of Poeppig from Cuba. Several authors subsequently confirmed the record for Cuba (Richard 1850, Grisebach 1866, 1873, Kränzlin 1892, Cogniaux 1909, Ames 1910, Galé 1938, León \& Schweinfurth 1946) and the several collections known from that country suggest that the species is relatively common there. In the 1920s, Ames (1922) recorded H. bicornis in Panama based on a single collection from the Canal Zone (Pittier 6792). Several other authors subsequently reported the species from Panama (Ames 1928, Williams 1946, 1956, Dressler 1980, 1993, D’Arcy 1987, Correa et al. 2004), but only one additional collection was made (Powell 315), with most workers simply quoting the original record without critical reexaminations of the identity of the specimen. Presence in Panama of a species previously known only from Cuba seemed curious, but no one investigated further the subject or revised the identity of the Panamanian specimens. In a synopsis of New World Habenaria, Batista et al. (2011a) noted that H. bicornis is similar to $H$. goyazensis Cogn. and that the identities of the two species should be assessed in more detail. Habenaria goyazensis was described by Cogniaux
(1893) based on a collection from central Brazil (Gardner 3995) and is currently known there from the Brazilian states of Goiás, Minas Gerais, Mato Grosso, Pará, Pernambuco, Sergipe, and Tocantins, as well as from Guyana (Batista et al. 2008, 2011a).

Here we investigated here the morphological and taxonomic relationships between $H$. bicornis and $H$. goyazensis based on examinations of the respective type material and additional herbarium collections. Based on a previous molecular phylogenetic analysis of New World Habenaria (Batista et al. 2013), we also assessed the phylogenetic relationships of $H$. bicornis, performed niche modeling analyses to infer the potential distribution of the species, and performed cytogenetic analyses to determine its chromosome number and CMA/DAPI banding patterns. This paper was prepared as part of the commemorations for the 40th anniversary of the Lankester Botanical Garden.

\section{Material and Methods}

Taxonomic analyses. - Descriptions were based on examination of pickled and herbarium material. Floral details were examined under a stereoscopic microscope and measured using a digital caliper. Gynostemium images of $H$. bicornis were done with a digital camera DFC295 coupled to a stereoscopic microscope (Leica M205C) and assembled using Leica Application Suite v. 3.8.0 software. Data relating to flowering times, habitat, and distribution were obtained from the labels of herbarium specimens. A total of 48 specimens and digital images (photographs) of $H$. bicornis were examined from the following herbaria: A, AMES, BHCB, BM, BR, CEN, EAN, EAP, G, GH, HB, IPA, K, MO, NY, OXF, P, RENZ, S, SP, US, and W. In addition to these herbaria, material of morphologically similar species were examined from: ALCB, B, CEPEC, CESJ, CTES,ESA, HBG, HRB, HRCB, HUEFS, IBGE, ICN, L, LP, M, MBM, MBML, OUPR, PMSP, R, RB, SI, SPF, UB, U, and UEC. Descriptive terminology is based on Stearn (1992) and Simpson (2006).

Taxon sampling for phylogenetic analyses. - The datasets for the phylogenetic analyses consisted of the combined ITS and partial matK DNA sequences of 208 terminals of 157 Neotropical Habenaria species, corresponding to $52 \%$ of the total number 
TABLE 1.Voucher information and GenBank accessions for the new sequences produced for this work.

\begin{tabular}{l|l|l|l|l}
\hline Taxon & Voucher & Origin & ITS & matK \\
\hline Habenaria bicornis Lindl. & L.P. Felix 10803 (EAN) & Brazil: Paraíba & KF998087 & KF998088 \\
\hline
\end{tabular}

of species known from the Neotropics (Batista et al. 2011a, 2011b); four African Habenaria species and Gennaria diphylla Parl. were was used as the functional outgroup. This dataset is basically the same used to infer phylogenetic relationships of New World Habenaria by Batista et al. (2013), but including Habenaria bicornis and excluding most of the Old World taxa. Voucher information, geographic origins, and GenBank accession numbers can be found in Batista et al. (2013); information concerning the newly sequenced accessions is provided in Table 1.

Molecular markers. - Nucleotide sequences from one nuclear (ITS) and one plastid ( $m a t K$ ) genome regions were analyzed. The ITS region consisted of the 3' and 5 ' ends of the $18 \mathrm{~S}$ and $26 \mathrm{~S}$ ribosomal RNA genes, respectively, the internal transcribed spacers (ITS1 and ITS2), and the intervening 5.8S gene of the nuclear ribosomal multigene family. Amplifications of this region were performed using primers $17 \mathrm{SE}$ and $26 \mathrm{SE}$ (Sun et al. 1994). We used an internal fragment of approximately $630 \mathrm{bp}$ of the $m a t K$ gene, amplified with primers matK-F2 and matK-R2 (Batista et al. 2013), which approximately corresponds to the region widely used for barcoding land plants (Chase et al. 2007). This fragment is the most variable region of the gene in several orchid groups (e.g., Whitten et al. 2000). DNA extraction, amplification, and sequencing were carried out following standard protocols, as described by Batista et al. (2013). Bidirectional sequence reads were obtained for all of the DNA regions, and the resulting sequences were edited and assembled using the Staden Package software (Bonfield et al. 1995). The edited sequences were aligned with MUSCLE (Edgar 2004), and the resulting alignments were manually adjusted using MEGA4 software (Tamura et al. 2007).

Phylogenetic analyses. - The data were analyzed by means of parsimony and Bayesian inference. Searches were performed only with a combined matrix, because no cases of strongly supported incongruence were detected in our previous analyses with the same datasets (Batista et al. 2013). Phylogenetic analyses using maximum parsimony (MP) were performed using PAUP* version 4 (Swofford 2002) with Fitch parsimony (equal weights, unordered characters; Fitch 1971) as the optimality criterion. Each search consisted of 1,000 replicates of random taxon additions, with branch swapping using the tree-bisection and reconnection (TBR) algorithm, saving $\leq 10$ trees per replicate to avoid extensive swapping on suboptimal islands. Internal support was evaluated by character bootstrapping (Felsenstein 1985) using 1,000 replicates, simple addition, and TBR branch swapping, saving $\leq 10$ trees per replicate. For bootstrap support levels, we considered bootstrap percentages (BPs) of $50-70 \%$ as weak, $71-85 \%$ as moderate, and $>85 \%$ as strong (Kress et al. 2002).

Bayesian analysis was conducted using MrBayes v. 3.1.2 (Ronquist et al. 2005), treating each DNA region as a separate partition. An evolutionary model for each DNA region was selected using the Akaike Information Criterion (AIC) in MrModeltest 2 (Nylander 2004). Each analysis consisted of two independent runs, each with four chains, for $5,000,000$ generations, sampling one tree every 1000 generations. To improve chain swapping, the temperature parameter for heating the chains was lowered to 0.01 in the combined analysis. Convergence between the runs was evaluated using the average standard deviation of split frequencies $(<0.01)$. After discarding the first $50 \%$ of the trees as the burn-in, the remaining trees were used to assess topology and posterior probabilities (PPs) in a majority-rule consensus. PPs in Bayesian analysis are not directly comparable to BPs, being generally much higher (Erixon et al. 2003). Therefore, we used criteria similar to a standard statistical test, considering groups with PPs $>0.95$ as strongly supported, groups with PPs ranging from 0.90-0.95 as moderately supported, and groups with PPs $<0.90$ as weakly supported. 
Niche modeling. - We assembled a database of 40 taxonomically depurated, georeferenced unique occurrence records, based on revision of specimens from 22 herbaria (see Taxonomic analyses, earlier). The geographic coordinates were plotted using ESRI ArcGIS 9 software. The extent of occurrence (EOO) was calculated by tracing a minimum polygon, with angles exceeding $180^{\circ}$ and containing all points of occurrence (IUCN 2010). The environmental variables were extracted from the database in Worldclim (Hijmans et al. 2005) at a spatial resolution of 0.98 $\mathrm{km}$. Niche model was generated using Maxent version 3.3.2 (Phillips et al. 2006, Sérgio et al. 2007) under the default values. The threshold was determined to turn the probability model into a model of presence and absence designed to distinguish appropriate and inappropriate areas for $\mathrm{H}$. bicornis. We adopted the Lowest Presence Threshold (LPT) method, which is suitable for guiding field studies whose main purpose is to identify unknown distribution areas and to find new populations (Pearson et al. 2007). GIS techniques were applied (ESRI ArcGIS 9.2) for the visualization of modeling results and a presence and absence value of 0.15 was adopted (LPT) to view the predicted area. The model was evaluated based on the jackknife method developed by Pearson et al. (2007).

CMA/DAPI banding and FISH (fluorescent in situ hybridization). - Root tips from specimen L.P Felix 10803 were pretreated with $0.002 \mathrm{M}$ of 8-hydroxyquinoline for $24 \mathrm{~h}$ at $10{ }^{\circ} \mathrm{C}$ and fixed in Carnoy's solution. CMA/DAPI banding and FISH procedures were performed according to Souza et al. (2012). Fixed root tips were washed in distilled water and digested in a $2 \%(\mathrm{w} / \mathrm{v})$ cellulase (Onozuka) $/ 20 \%$ $(\mathrm{v} / \mathrm{v})$ pectinase (Sigma) solution at $37{ }^{\circ} \mathrm{C}$ for 120 min and macerated in a drop of $45 \%$ acetic acid; the coverslip was later removed in liquid nitrogen. The CMA/DAPI double-staining technique was used for fluorochrome banding. Slides were aged for 3 days, stained with CMA $\left(0.1 \mathrm{mg} \mathrm{mL}^{-1}\right)$ for 60 min, re-stained with DAPI $\left(1 \mu \mathrm{g} \mathrm{mL} L^{-1}\right)$ for $30 \mathrm{~min}$, mounted in glycerol:Mcllvaine buffer pH 7.0 (1:1), and subsequently aged for 3 days before analysis in an epifluorescence Leica DMLB microscope. Images were captured with a Cohu CCD video camera using Leica QFISH software, and were subsequently edited in Adobe Photoshop CS3 version 10.0. The rDNA sites were localized using 5S rDNA from Lotus japonicus (Regel) K.Larsen labeled with Cy3-dUTP (Amersham) and 45S rDNA from Arabidopsis thaliana (L.) Heynh. labeled with digoxigenin-11-dUTP as probes. Labeling was performed by nick translation. The 45S rDNA probe was detected with sheep antidigoxigenin FITC conjugate (Roche) and amplified with rabbit anti-sheep FITC conjugate (Dako). The hybridization mixture contained $50 \%$ formamide $(\mathrm{v} / \mathrm{v}), 10 \%$ dextran sulfate (w/v), $2 \times \mathrm{SSC}$, and $5 \mathrm{ng} /$ $\mu \mathrm{L}$ of each probe. The slides were denatured at $75 \mathrm{oC}$ for $3 \mathrm{~min}$. Stringent washes were performed, reaching a final stringency of approximately $76 \%$. Images of the best cells were captured as previously described.

\section{Results and discussion}

Taxonomic and morphological analyses. Examination and comparison of the type specimens and several other collections of H. bicornis and H. goyazensis (see list of the materials examined) revealed that the two concepts are conspecific, sharing the following distinctive characters: welldeveloped, patent, lanceolate leaves up to $28 \mathrm{~cm}$ long and $2.5 \mathrm{~cm}$ wide; medium-sized flowers (dorsal sepal 4-8 $\mathrm{mm}$ long), anterior petal segment longer than the posterior segment; and spur 2.5-4.6 cm long, being about 1.3-2.1 times as long as the pedicellate ovary (Fig. 1 and Table 2). In terms of the overall morphology of the flowers, Habenaria bicornis shares some similar characters with, and has been mistaken for, other species such as H. caldensis Kraenzl. and H. exaltata Barb.Rodr. (Fig. 2) that also have a spur approximately twice the size of the pedicellate ovary

Right, Figure 1. Floral and vegetative morphology of Habenaria bicornis and similar species. From left to righ on each row: lateral view of ovary, spur and gynostemium, dissected perianth, and habit. Habenaria bicornis. A - Batista 683, CEN. B - Santos et al. 2422, CEN. C - Pastore 1452, BHCB. Habenaria caldensis. D - Batista et al. 1382, CEN. E-Batista 2415, BHCB. F - Borba 102, BHCB. G - Munhoz \& Martins 94, BHCB. Habenaria exaltata. H, I - Batista 2798, BHCB. J - Batista 2520, BHCB. Habenaria rodeiensis. K, M - Batista \& Peixoto 3273, BHCB. $\mathrm{L}$ - Mota 2824, BHCB. Scales $=1 \mathrm{~cm}$, for ovary, spur, gynostemium, and dissected perianth; $5 \mathrm{~cm}$ for habit. 


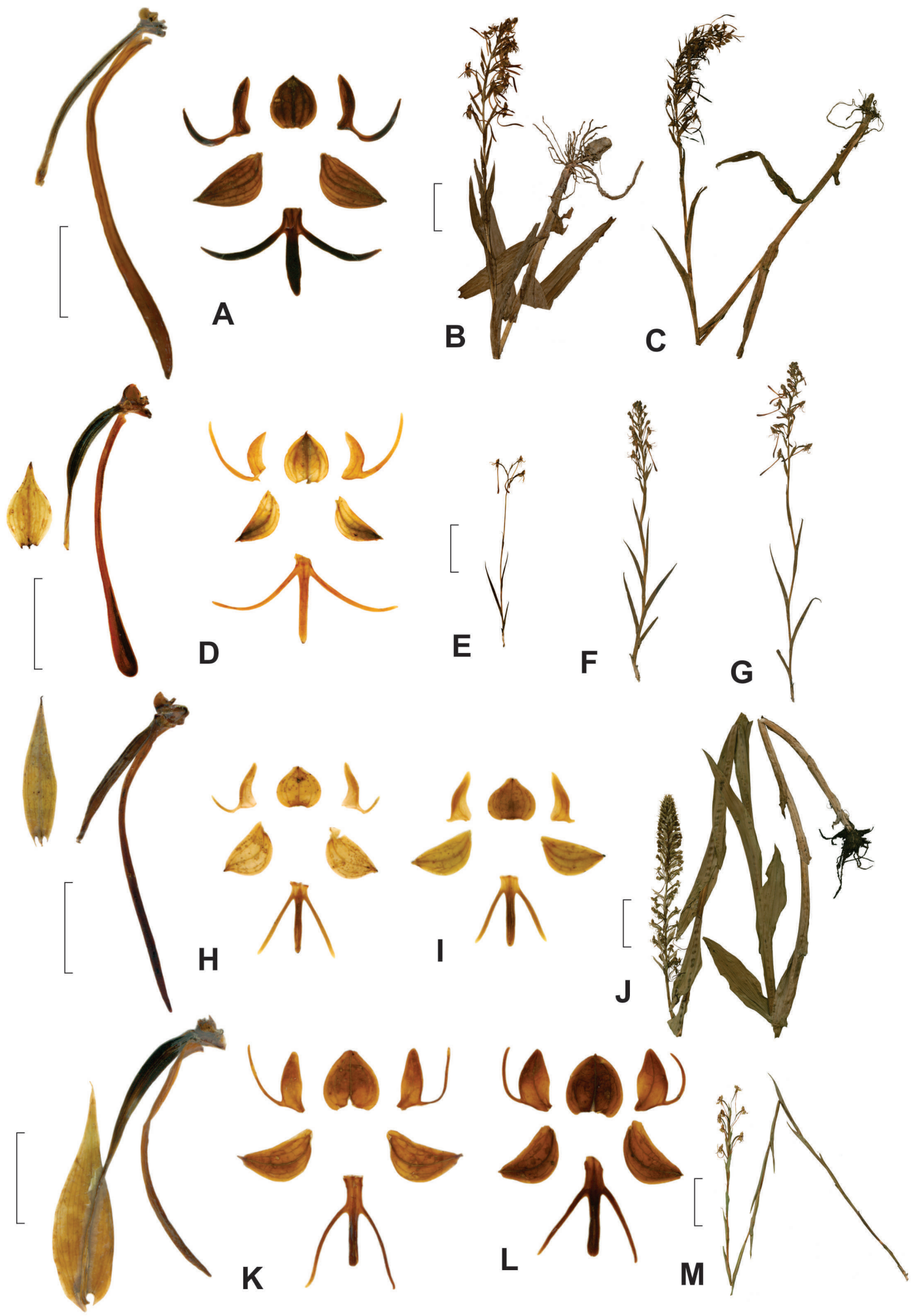


TABLE 2. Diagnostic characters comparing H. bicornis and morphologically similar species. Abbreviations for the Brazilian states are: BA, Bahia; DF, Distrito Federal; ES, Espirito Santo; GO, Goiás; MG, Minas Gerais; MT, Mato Grosso; PA, Pará; PB, Paraíba; PE, Pernambuco; PR, Paraná; RJ, Rio de Janeiro; RS, Rio Grande do Sul, SE, Sergipe; SP, São Paulo; TO, Tocantins.

\begin{tabular}{|c|c|c|c|c|}
\hline & H. bicornis & H. caldensis & H. exaltata & H. rodeiensis \\
\hline $\begin{array}{l}\text { Leaves length } \times \\
\text { width }(\mathrm{cm})\end{array}$ & $13-24(28) \times(0.8) 1.1-2(2.5)$ & $5-12(16) \times 0.3-0.9(1.4)$ & $8.5-28 \times 1.5-3.5$ & $5-12 \times 0.6-1.6$ \\
\hline $\begin{array}{l}\text { Dorsal sepal length } \times \\
\text { width }(\mathrm{mm})\end{array}$ & $4-8 \times 4.5-6(8)$ & $5-7 \times 4.5-6$ & $3.7-5.3 \times 3.8-5.8$ & $4.5-7 \times 4-6$ \\
\hline $\begin{array}{l}\text { Lateral sepals length } \\
\times \text { width }(\mathrm{mm})\end{array}$ & $6.5-9.5 \times 3-5$ & $6.2-8.8 \times 2.6-3.8$ & $4.7-7.8 \times 2.3-4.4$ & $5.5-8 \times 2.5-3$ \\
\hline Corola color & $\begin{array}{l}\text { base white, segments } \\
\text { green }\end{array}$ & white throughout & $\begin{array}{l}\text { base whitish, segments } \\
\text { green }\end{array}$ & $\begin{array}{l}\text { base white, segments } \\
\text { light green to whitish }\end{array}$ \\
\hline $\begin{array}{l}\text { Posterior petal } \\
\text { segment length } \times \\
\text { width }(\mathrm{mm})\end{array}$ & $4.6-7.1 \times 1.7-1.85$ & $4.8-6 \times 1.3-1.8$ & $3.7-5.7 \times 1-1.8$ & $4.5-7.5 \times 2-3.5$ \\
\hline $\begin{array}{l}\text { Anterior petal } \\
\text { segment length }(\mathrm{mm})\end{array}$ & $6.8-8.8$ & $8-13$ & $1.2-4.4$ & $4.5-6(7)$ \\
\hline $\begin{array}{l}\text { Anterior petal } \\
\text { segment length } \\
\text { relative to posterior } \\
\text { segment }\end{array}$ & $1.3-1.5$ times as long & 1.6-2.2 times as long & $0.2-1$ times as long & $1-1.2$ times as long \\
\hline Ovary length (mm) & $13-28$ & $10-14$ & $11-15$ & $12-16$ \\
\hline Pedicel length (mm) & $2.3-6$ & $5-8$ & $1.5-4.4$ & $18-28$ \\
\hline Spur length (mm) & $25-46$ & $32-41$ & $28-35$ & $28-36$ \\
\hline $\begin{array}{l}\text { Spur size relative to } \\
\text { the pedicelate ovary }\end{array}$ & 1.3-2.1 times as long & 1.6-2.3 times as long & $1.5-1.8$ times as long & $0.9-1.2$ times as long \\
\hline $\begin{array}{l}\text { Spur position relative } \\
\text { to floral bracts }\end{array}$ & free from the bracts & free from the bracts & free from the bracts & $\begin{array}{l}\text { placed between the } \\
\text { bracts }\end{array}$ \\
\hline Spur & clavate & clavate & linear & linear \\
\hline Spur apex & subacute to acute & rounded & acute & acute \\
\hline Hemipollinaria & separated & united & separated & united \\
\hline $\begin{array}{l}\text { Rostellum midlobe } \\
\text { apex }\end{array}$ & $\begin{array}{l}\text { obtuse, placed between } \\
\text { the anther loci }\end{array}$ & $\begin{array}{l}\text { acute, projected } \\
\text { beyond the anther loci }\end{array}$ & $\begin{array}{l}\text { obtuse, placed between } \\
\text { the anther loci }\end{array}$ & $\begin{array}{l}\text { subacute, projected } \\
\text { beyond the anther loci }\end{array}$ \\
\hline Distribution & $\begin{array}{l}\text { Mexico, Guatemala, } \\
\text { Honduras, Panama, } \\
\text { Cuba, Venezuela, Guyana } \\
\text { and Brazil (PA, PB, PE, } \\
\text { SE, GO, MT, TO, MG) }\end{array}$ & Brazil (BA, GO, MG) & $\begin{array}{l}\text { Brazil (MG, PR, RS, SP) } \\
\text { and Paraguay }\end{array}$ & $\begin{array}{l}\text { Brazil (BA, DF, ES, GO, } \\
\text { MG, MT, PR, RJ, SP), } \\
\text { Paraguay and Peru* }\end{array}$ \\
\hline
\end{tabular}

*The records of $H$. rodeiensis from northern South America and Central America in Belize, Costa Rica and French Guiana need confirmation because this species is remarkably similar to $H$. longipedicellata, H. lehmanniana Kraenzl., and H. ernestii Schltr. That are known from northern Brazil or northern South America, and the separations between them are not clear.

(Fig. 1, and Table 2). However, H. caldensis differs in the smaller plants with smaller leaves, a completely white corolla, anterior petal segment 1.6-2.2 times as long as the posterior segment, and rounded spur apex. On the other hand, H. exaltata is distinguished from $H$. bicornis by its shorter anterior petal segment
(1.2-4.4 mm long), which is about $0.2-1$ times as long as the posterior segment, and the spur linear throughout (Figs. 1, 2; Table 2). Other differences are found in the morphology of the gynostemium: in $H$. bicornis the midlobe apex of the rostellum is obtuse, placed between the anther loci and the hemipollinaria 


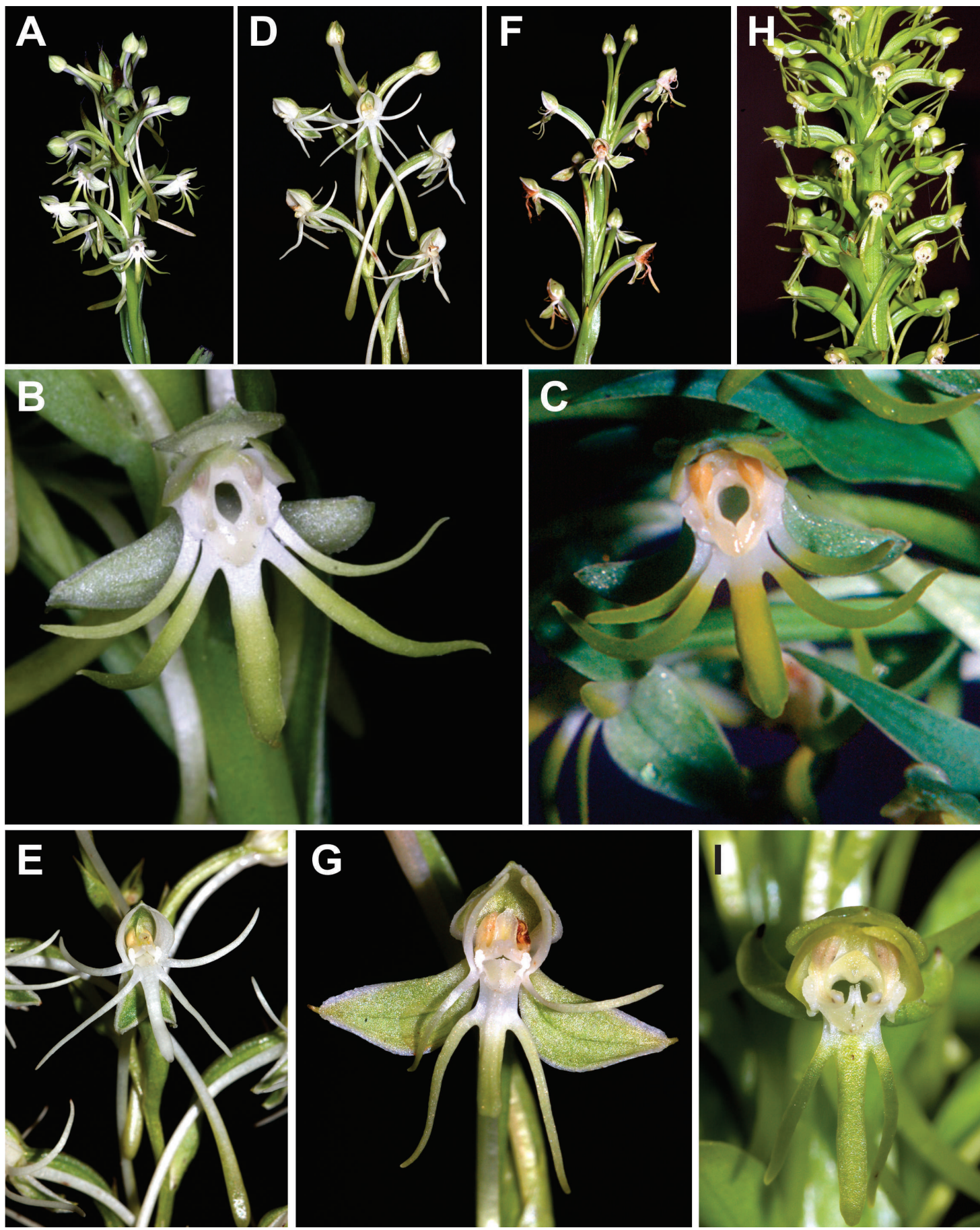

Figure 2. Inflorescences and flower morphology of Habenaria bicornis and similar species. Habenaria bicornis. A - Inflorescence. B - Flower, both from Felix 10803, EAN. C — Flower, from Batista 683, CEN. Habenaria caldensis. D - Inflorescence, from Batista 2633, BHCB. E - Flower, from Batista 2621, BHCB. Habenaria rodeiensis. F - Inflorescence. G - Flower, both from Batista \& Peixoto 3273, BHCB. Habenaria exaltata. H - Inflorescence. I - Flower, both from Batista et al. 2520, BHCB. 

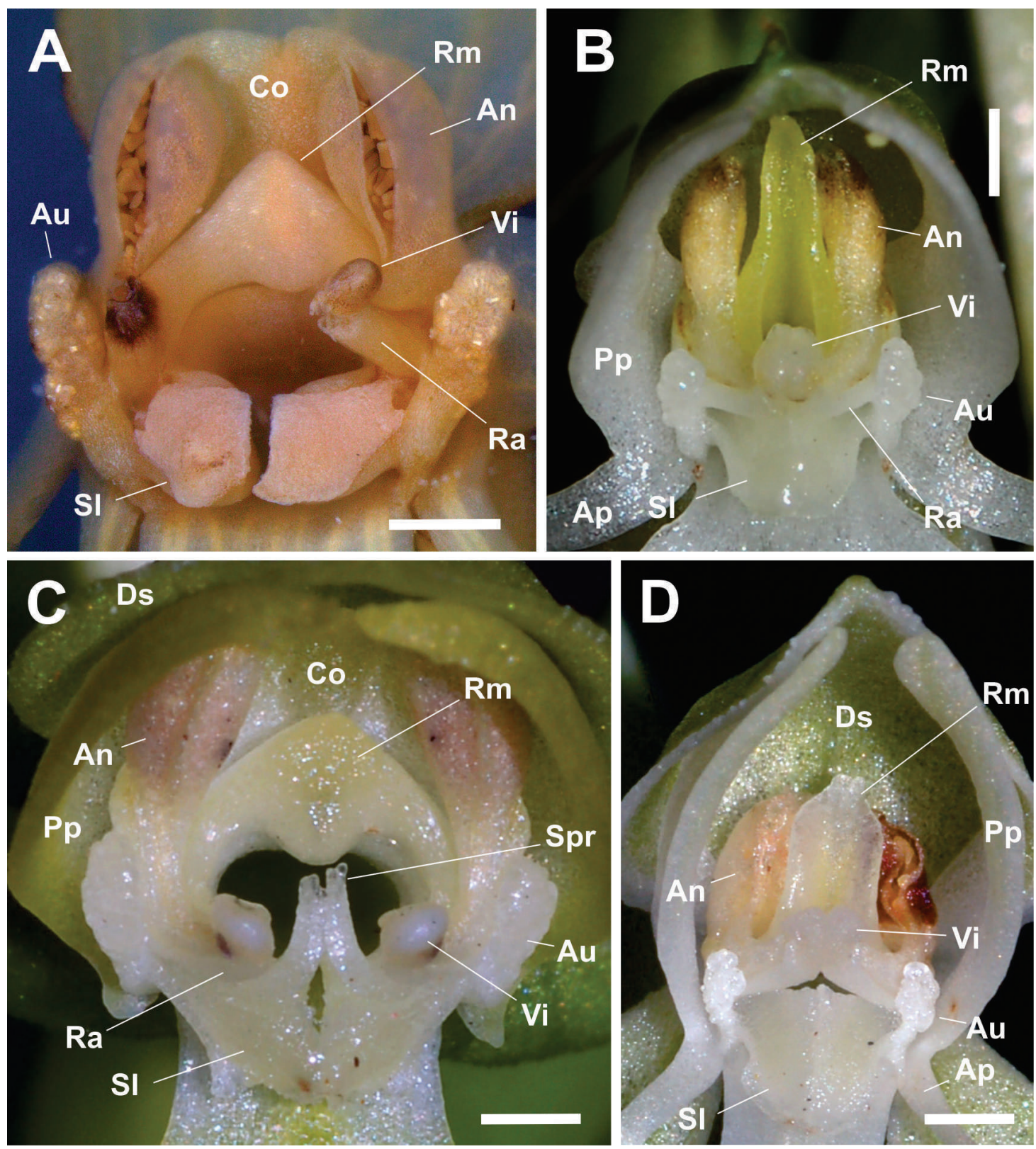

Figure 3. Gynostemium morphology. A - Habenaria bicornis, from Batista et al. 683, CEN. B — Habenaria caldensis, from Batista 2621, BHCB. C - Habenaria exaltata, from Batista et al. 2520, BHCB. D - Habenaria rodeiensis, from Batista \& Peixoto 3273, BHCB. Scale bars A = $2 \mathrm{~mm}$; B-D = $1 \mathrm{~mm}$. Ac = anther canals; An = anther; Ap = anterior petal lobe; $\mathrm{Au}=$ auricules; $\mathrm{Co}=$ connective; $\mathrm{Ds}=$ dorsal sepal; $\mathrm{Pe}=$ petal; $\mathrm{Pg}=$ pollen grains; $\mathrm{Pp}=$ posterior petal lobe; $\mathrm{Ra}=$ rostellum arms; $\mathrm{Rm}=$ rostellum midlobe; $\mathrm{Sp}=$ stigmatic lobes; $\mathrm{Spr}=$ stigmatic projections; $\mathrm{Vi}=$ viscidium.

are separated, whereas in $H$. caldensis the rostellum midlobe apex is acute, projected beyond the anther loci, and the hemipollinaria are united (Fig. 3). In $H$. exaltata the stigma lobes have a protruding, erect projection that partially divides the space between the stigma lobes and the entrance to the spur into two apertures (Fig. 3), which is a very distinctive character not found in any of the other species mentioned 
above. Habenaria bicornis has also been confused with $H$. rodeiensis Barb. Rodr. However, the leaves of the latter are smaller and more appressed to the stem, the pedicel is about the same size or longer than the ovary, the spur is linear throughout and usually covered by the bracts, the posterior segment of the petals is wider (Fig. 1; Table 2), and the hemipollinaria are united by the viscidia (Fig. 3). Further differences between $H$. bicornis and the species mentioned above are outlined in the key below and in Table 2.

With few exceptions, the identification of specimens of $H$. bicornis has been straightforward. This species was previously only known from Cuba, and is very distinct from other Cuban species of Habenaria. The identity of $H$. goyazensis and its taxonomic history, on the other hand, has been confusing because each taxonomist who examined material of the species (Cogniaux 1893, Kränzlin 1911, Hoehne 1940, Pabst \& Dungs 1975, Snuverink \& Westra 1983, Renz 1992) misidentified it or applied that name to other species. Lindley was apparently the first to examine collections of $H$. goyazensis because there is a sheet in his herbarium (K-L) with drawings of a plant and a flower (Fig. 4) of the type collection (Gardner 3995), but he apparently never assigned a name to this material. There is also a duplicate of the type collection (W-R 51336) at the Reichenbach herbarium (W-R) and another sheet in the same herbarium (W-R 54022) bearing a sketch of a flower from the type made by Reichenbach (Fig. 4), as well as a reproduction of Lindley's drawings at K-L. Curiously, the two major orchid taxonomists of the 19th century examined collection Gardner 3995 in detail (judging from the illustrations they drew; Fig. 4), but neither reached a conclusion about its identity.

For his description of $H$. goyazensis, Cogniaux (1893) apparently did not examine duplicates of the type material nor the illustrations located at K-L and $\mathrm{W}-\mathrm{R}$, as his protologue only mentions material from $\mathrm{B}$ and G. Cogniaux's herbarium, now in BR, holds a fragment of the type collection of $H$. goyazensis as well as a complete specimen of the species (Pohl s.n.), although the latter is misidentified as $H$. sartor Lindl. Kränzlin (1911) examined two collections of $H$. goyazensis from Mato Grosso, Brazil, but identified one as H. exaltata (Lindman 2765) and the other as H. caldensis (Lindman 27911/2). Hoehne (1940) examined and correctly identified the collection
Pickel 3615, which is H. goyazensis, but his concept of the species was equivocal, as he used the same name for another species, currently known as $H$. tamanduensis Schltr. Pabst (Pabst \& Dungs 1975) apparently only examined one collection of the species (Macedo 1695), which he identified as H. caldensis, using the name $H$. goyazensis for several other species (including $H$. caldensis, H. dusenii Schltr., H. glaucophylla Barb. Rodr., H. longipedicellata Hoehne, H. macilenta [Lindl.] Rchb.f., and $H$. rodeiensis). Other extra-Brazilian South American collections of $H$. goyazensis remained indeterminate or were more recently identified as $H$. caldensis by Snuverink \& Westra (1983) and Renz (1992).

Excluding the material from Panama, other Central American and Mexican specimens of $H$. bicornis remained indeterminate or received disparate identifications (such as $H$. bractescens Lindl. or $H$. jaliscana S. Watson). Ames (1922, 1928) was the only taxonomist able to correctly identify extraCuban specimens of $H$. bicornis; probably because he had personally examined and correctly identified several specimens from Cuba.

Phylogenetic analyses. - The matrix with the combined ITS and partial matK gene consisted of 1372 aligned characters, of which 304 (22\%) were parsimony-informative. The parsimony analysis retained a total of 5150 most parsimonious trees with a tree length of 935 steps, a consistency index (CI) of 0.65 , and a retention index (RI) of 0.85 . The strict consensus of 5150 trees was for the most congruent with the Bayesian majority-rule consensus tree, but because the latter was more fully resolved and had stronger overall support it was chosen for presentation here (Fig. 5). The relationships recovered were similar to those of our previous molecular phylogenetic study (Batista et al. 2013), with the New World Habenaria species forming a well-supported monophyletic group (1.00 PP, 87\% BS, Fig. 5) that was sister to the African species $H$. tridens Lindl. (1.00 PP, 100\% BS). Within the New World clade, several well-supported subclades were recovered (Fig. 5) that corresponded to the same subclades identified in our previous analyses (Batista et al. 2013). Habenaria bicornis formed a polytomy $(0.75 \mathrm{PP})$ with a clade formed by subclades 2 and 3 and another formed by subclades 4 


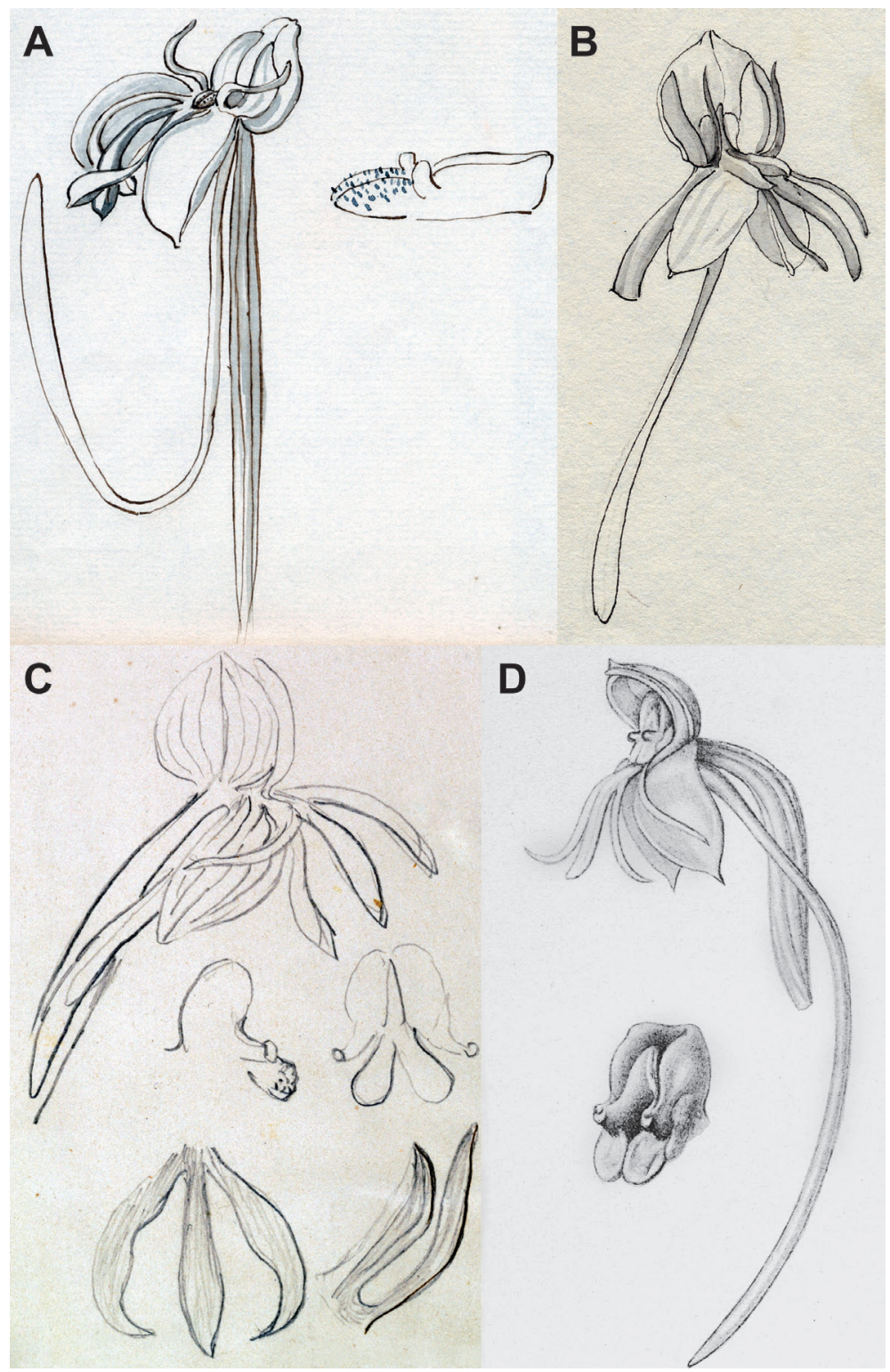

FiguRE 4. Historical illustrations of Habenaria bicornis and H. goyazensis. A - Habenaria bicornis. Lindley's original drawing of the species based on the holotype: E.F. Poeppig s.n. (K-L 000463128). B - Habenaria goyazensis. Lindley's drawing of the type material based on G. Gardner 3995(K-L 000363784). C - Habenaria goyazensis. Reichenbach's drawing of the type material (Gardner 3995), probably from W-R 51336. D - Habenaria goyazensis. Drawing published by Kränzlin (1911) based on Lindman 2791 1/2 (S 06-6545). A and B reproduced with the permission of the Royal Botanic Gardens, Kew. C provided by the National History Museum, Vienna.

Right, FiguRE 5. Bayesian majority-rule consensus tree of the combined ITS and matK (partial) datasets. Numbers next to the nodes represent the posterior probabilities from the Bayesian analysis (PPs) and bootstrap values from the parsimony analysis (PP/MP). Bootstrap values $\leq 50 \%$ are shown by a dash (-). Only values of the major clades are shown. Neotropical subgroups are numbered according to Batista et al. (2013). Old World taxa are indicated by an asterisk (*). The generic name for all Habenaria species is abbreviated. Habenaria bicornis is highlighted in bold and indicated by an arrow. 


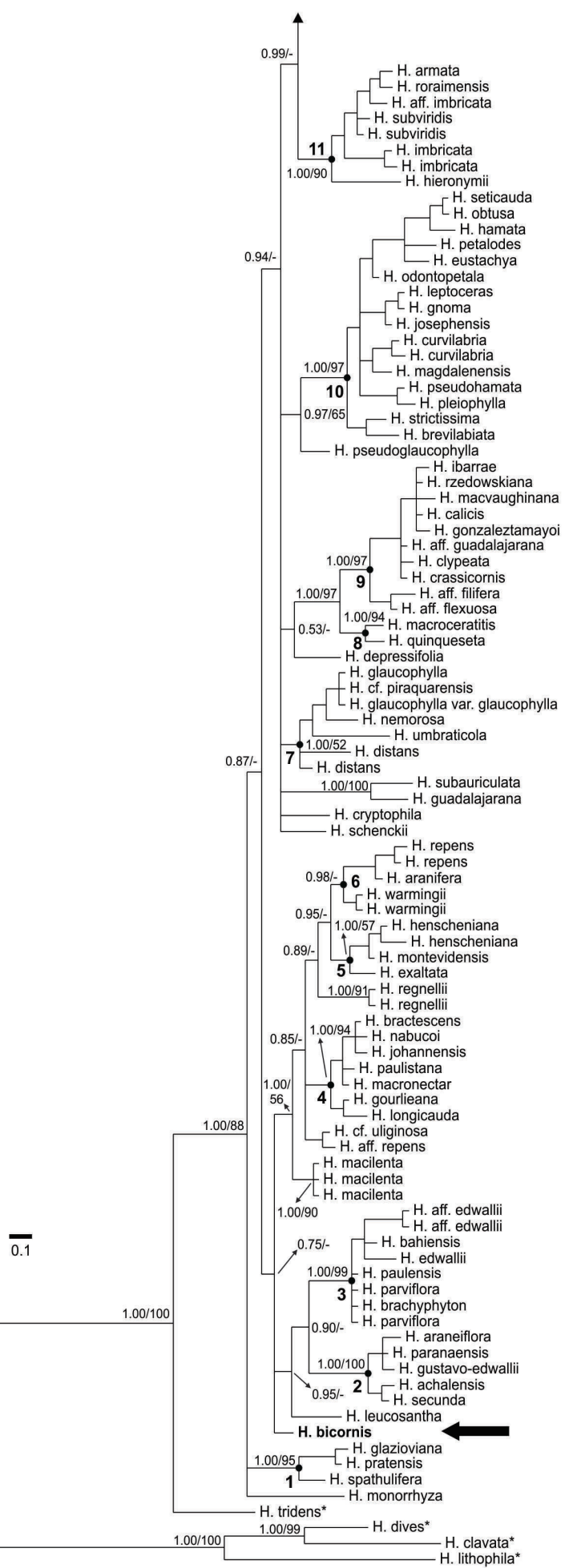

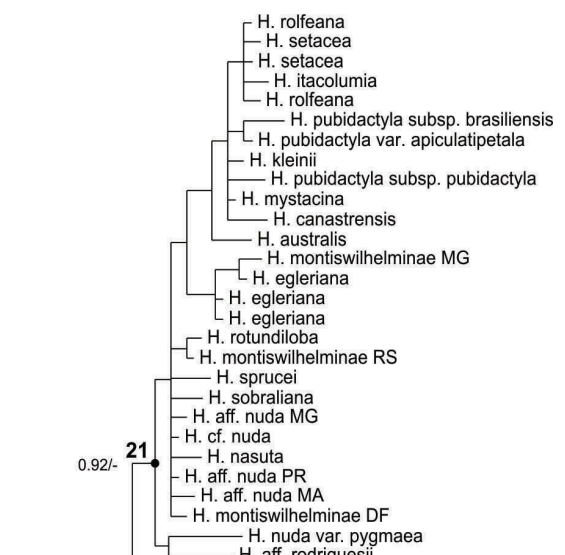

H. nuda var. pygma

$\mathrm{H}$. alpestris

H. schwackei

0.99/76 - H. schwackei

$20-\mathrm{H}$. heptadactyla

$\mathrm{H}$. leprieuri

H. aff. subfiliformis

H. pleprieurii8

$-\mathrm{H}$. canastrensis

$192 \mathrm{H}$. fluminensis

$\mathrm{H}$. lavrensis

H. aff. leprieurii201 27

H. aff. subfiliformisDF913

. ayangannensis

[ H. crucifera

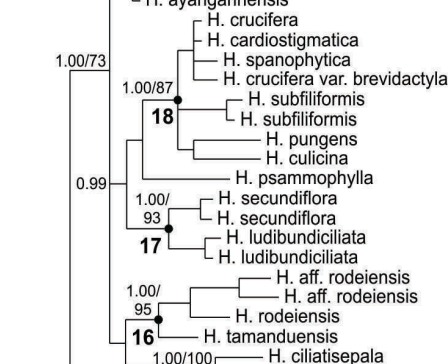

$1.00 / 100-\mathrm{H}$ ciliatisepar

H. ciliatisepala

$-\mathrm{H}$. balansae

- H. balansae

H. mellobarretoi

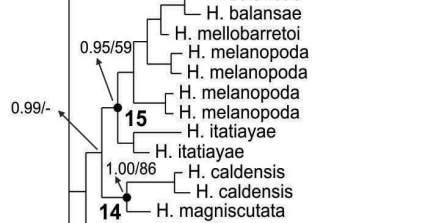

H. caldensis

H. humilis

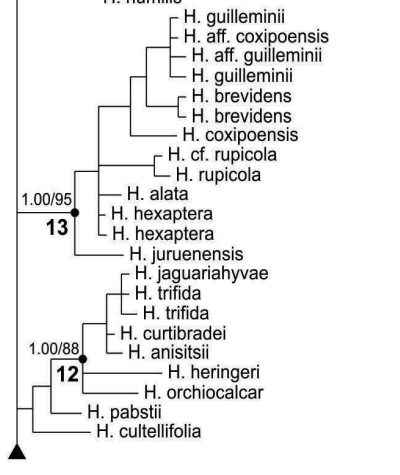


to 6 . In the strict consensus of the parsimony analysis this node collapsed and $H$. bicornis was placed in a polytomy near the base of the Neotropical clade.

In terms of infrageneric classifications, Kränzlin $(1892,1901)$ placed H. bicornis in sect. Macroceratitae Kraenzl., while Cogniaux (1893) and Kränzlin (1901) placed H. goyazensis in sect. Pentadactylae Kraenzl. These classifications are clearly equivocal because $H$. bicornis and $H$. goyazensis do not match the morphological characters of the corresponding sections, and also because all Neotropical sections of the genus are polyphyletic or paraphyletic (Batista et al. 2013).

The morphological relationships of $H$. bicornis with other Neotropical species or subclades are likewise unclear because Habenaria bicornis is morphologically distinct from any of the basal subclades (Fig. 5, subclades 2 to 6) and any other Neotropical subclade.

Niche modeling. - The potential distribution of $H$. bicornis as modeled with Maxent using the threshold (LPT) value of 0.151 as the upper limit is shown in figure 6 . The hit ratio generated by this model was $93 \%$. The potential geographic distribution of the species extends from the Atlantic coast of the state of VeraCruz in Mexico, southwards to the coast of Santa Catarina State in southern Brazil, and eastwards to the Bahamas, northeastern Brazil, and the Guyanas. The bioclimatic variables that contributed most to the model were mean monthly diurnal temperature ranges (maximum temperature minus minimum temperature), precipitation seasonality, and annual temperature range (maximum temperature of warmest month minus minimum temperature of coldest month). Distribution modeling predicted a larger area of occurrence than that currently known for the species, which includes the Yucatan Peninsula in Mexico, Guatemala, Honduras, Panama, Cuba, Venezuela, Guyana, and Brazil. According to our results, however, H. bicornis should also be expected to occur in Belize, Nicaragua, Costa Rica, all the major islands of the Antilles, as well as Colombia, Suriname, Ecuador, Peru, Bolivia and Paraguay. Many of the predicted areas of occurrence should be expected based on the current known distribution of the species, such as other Mesoamerican countries and some areas of northeastern Brazil. However,

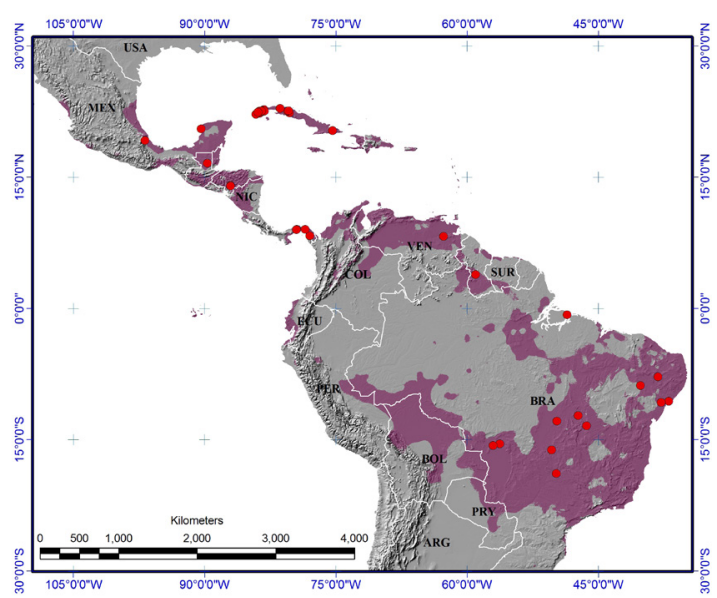

FIGURE 6. Occurrence records and potential distribution of Habenaria bicornis inferred with Maxent. Political divisions are highlighted in white. Country abbreviations are as follows: Arg, Argentina; Bol, Bolivia; Bra, Brazil; Col, Colombia; Ecu, Ecuador; Mex, Mexico; Nic, Nicaragua; Per, Peru; Pry, Paraguay; Sur, Suriname; Ven, Venezuela.

some high probability areas of occurrence were unexpected, such as the coastline of Ecuador and parts of the states of Rio de Janeiro and Espirito Santo in southeastern Brazil (Fig. 6).

Cytogenetics. - Habenaria bicornis has $2 n=42$ (Fig. 7A-C, G) and a symmetrical karyotype, with chromosomes ranging in size from 2.9 to $9.8 \mu \mathrm{m}$ and being mainly metacentric to submetacentric, except for two small acrocentric pairs (Fig. 7C, arrows). Regular meiosis was observed, with 21 chromosomes in each cell of the dyad in meiosis II (Fig. 7D-F). Although the species did not show clearly differentiated CMA/DAPI bands in meiosis, CMA-/DAPI+ pericentromeric regions (Fig. 7A, B) were observed in mitosis. Terminal chromosome regions staining slightly more intensely with CMA than with DAPI were observed only in mitotic prometaphases (Fig.7C). Two 45S rDNA sites were observed on the terminal chromosome regions of a large metacentric pair (Fig. 7G) that did not cooccur with CMA bands. Two 5S rDNA sites were observed in the interstitial and subterminal regions of a long arm on two chromosome pairs per monoploid complement (Fig. 7G). The basic number $x=21$ is the most frequent among Neotropical and Old World 

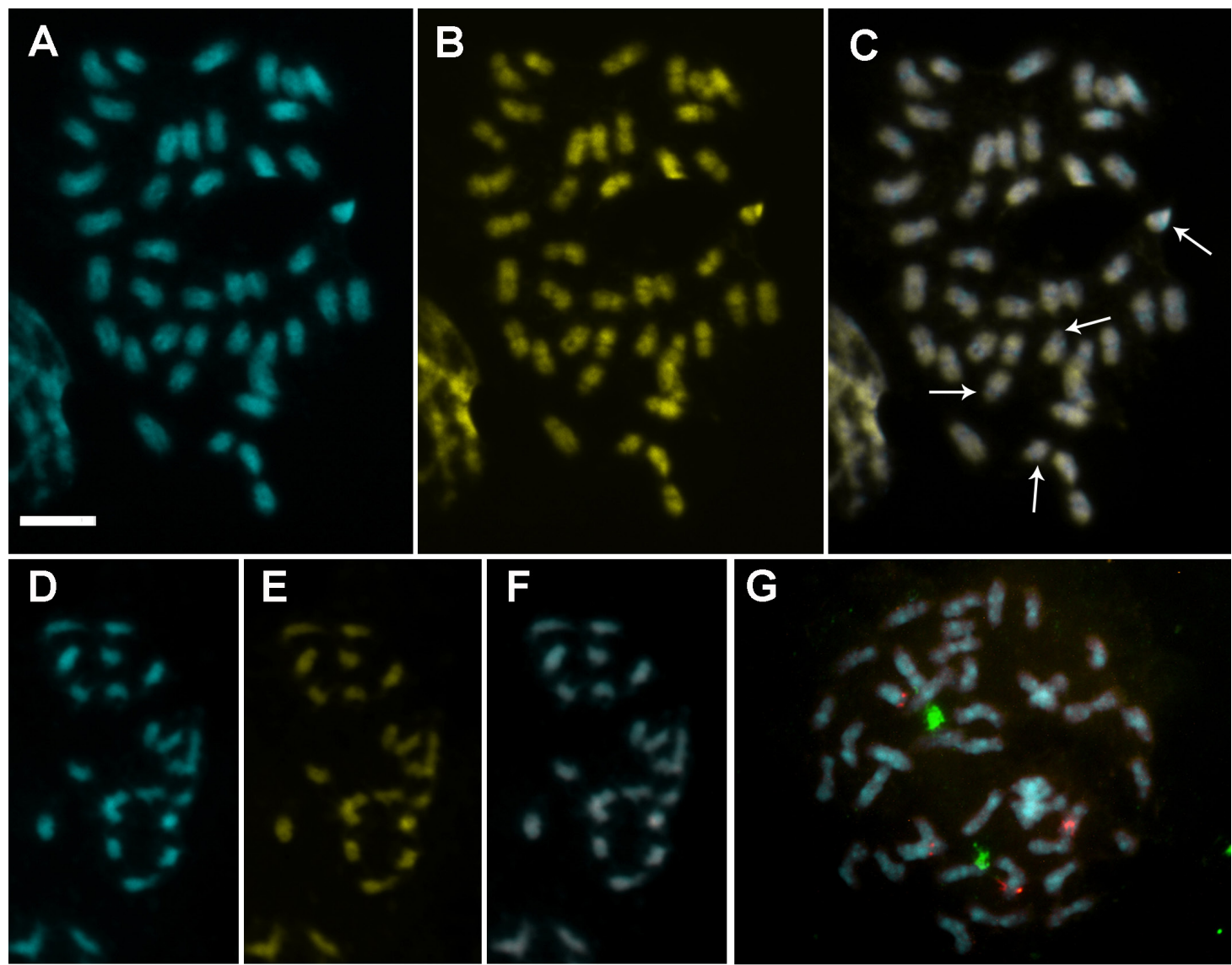

Figure 7. Habenaria bicornis. A-C, G. Mitotic metaphases. D-F. Meiotic metaphase II. A, D. Stained with DAPI. B, E. Stained with CMA. C, F. CMA/DAPI overlap showing CMA terminal bands and DAPI pericentromeric bands. G. FISH with 45S (green) and 5S rDNA sites (red). Arrows in C indicate acrocentric chromosomes; scale bar in A corresponds to $10 \mu \mathrm{m}$.

species of Habenaria (Felix \& Guerra 1998, 2005). This number was previously reported for $H$. pratensis (Salzm. ex Lindl.) Rchb.f. and H. repens Nutt. (Felix \& Guerra 1998), both of which are "basal" species in our previous molecular phylogenetic analysis of Neotropical Habenaria (Batista et al. 2013), suggesting that $x=21$ maybe the ancestral basic number for Neotropical Habenaria.

The banding patterns observed in H. bicornis stand out because of the presence of pericentromeric and terminal heterochromatin. Pericentromeric heterochromatin has been observed in unrelated groups of orchids, such as Psygmorchis pusilla (L.) Dodson \& Dressler (Felix \& Guerra 1999; Epidendroideae, Oncidiinae), several species of Ophrys L. (D'Emerico et al. 2005; Orchidoideae,
Orchidiinae), and Heterotaxis discolor (Lodd. ex Lind1.) Ojeda \& Carnevali (Cabral et al. 2006; Epidendroideae, Maxillariinae), suggesting that the loss or acquisitions of this heterochromatin may be recurrent events in orchids. However, the occurrence of GC-rich heterochromatin on the terminal regions of all chromosomes in $H$.bicornis has not been reported for any other orchid species. The evolution of CMA/DAPI band patterns in subtribe Maxillariinae is highly variable within and between different monophyletic lineages and has been important for the cytotaxonomic characterization of several species (Moraes et al. 2012). If this is also true for Habenaria, CMA/DAPI band patterns may provide an additional tool for characterization of lineages and species and for testing phylogenetic hypothesis in the genus. 


\section{Taxonomic treatment}

Key to HaBENARIA BICORNIS AND MORPHOLOGICALLY SIMILAR SPECIES

1. Petal posterior segment $2.0-3.5 \mathrm{~mm}$ wide; spur about the same length as the pedicellate ovary, usually hidden between the bracts

H. rodeiensis

1. Petal posterior segment $1.0-1.85 \mathrm{~mm}$ wide; spur 1.3-2.3 times as long as the pedicellate ovary, free from the bracts

H. exaltata

2. Petal anterior segment $0.2-1.0$ times as long as posterior segment; spur linear throughout

2. Petal anterior segment 1.3-2.2 times as long as posterior segment; spur clavate to subclavate 3

3. Plants $19-44 \mathrm{~cm}$ tall including inflorescence; leaves $5-12(-16) \times 0.3-0.9(-1.4) \mathrm{cm}$; petals and lip completely white; anterior petal segment 1.6-2.2 times as long as posterior segment; spur apex rounded; hemipollinaria united; rostellum midlobe apex acute, projected beyond the anther locules

H. caldensis

3. Plants $(25-) 37-90(-107) \mathrm{cm}$ tall including the inflorescence; leaves $13-24(-28) \times(0.8-) 1.1-2.0(-2.5)$ $\mathrm{cm}$; petals and lip with base white and green segments; anterior petal segment $1.3-1.5$ times as long as posterior segment; spur apex subacute to acute; hemipollinaria separated; rostellum midlobe apex obtuse, situated between the anther locules

H. bicornis

Habenaria bicornis Lindl., Gen. Sp. Orchid. Pl. 309. 1835. Type: CUBA. 1822, E.F. Poeppig s.n. (Holotype: $\mathrm{K}$ [s.n.]; isotype: K-L [000463128, drawings of holotype by Lindley]).

Synonyms: Habenaria tricuspis A. Rich., Hist. Fis. Cuba, Bot. 11: 249. 1850. Type: CUBA. 1836, $R$. de La Sagra s.n. (Holotype: P [00408997]; isotype: W-R [43232]).

Habenaria goyazensis Cogn., Fl. Bras. (Martius) 3(4): 77. 1893. Type: BRAZIL. Goyaz [Tocantins], campos (marsh) near Conceição [Conceição do Tocantins], fls. greenish-white, February 1840 (fl), G. Gardner 3995 (Holotype: not indicated; Lectotype, designated by Batista et al. 2011a: K [000363814]; Isotypes: B [destroyed], BR [642571; fragment from B or G], BM [000032714], F [24791; negative from the specimen from G], G [00169025], K [000363815], K-L [000363784], OXF, W-R [51336, 54022], RENZ [1446; photo, drawing and fragment from W-R 51336]).

Terrestrial herb. Roots few, short, at the base of the stem. Tuberoid fusiform, $2.2-3.0 \times 1.0-1.8 \mathrm{~cm}$. Stem erect, (25-)37-90(-107) cm long, including the inflorescence, 3.0-7.7 mm wide. Leaves 6-10(-17), spreading, largest at the center of the stem, lanceolate, $13-24(-28) \times(0.8-) 1.1-2.0(-2.5) \mathrm{cm}$. Inflorescence 6-20 cm long, many-flowered, spiral; floral bracts lanceolate, acuminate, (1.3-)1.5-2.8(-3.2) cm long, shorter than or about the same size as the pedicellate ovary. Flowers 19-28(-33), resupinate, greenishwhite; pedicellate ovary parallel to or spreading from the rachis, (13-)21-26(-32) mm long; ovary slightly arched, 13-28 mm; pedicel shorter than the ovary, 2.3-4.2 mm. Sepals green, aristate, smooth; dorsal sepal concave, when flattened ovate, $4-8 \times 4.5-6.0(-8.0)$ $\mathrm{mm}$; lateral sepals obliquely lanceolate, acute or subacute, reflexed, 6.5-9.5 × 3-5 mm. Petals bipartite; posterior segment falcate, $4.6-7.1 \times 1.7-1.9 \mathrm{~mm}$, subacute, lying beside or free from the dorsal sepal, base, middle part and inner margin white, outer margin from the middle to the apex light green; anterior segment divergent, linear, inserted at the base of the posterior segment, $6.8-8.8 \times 0.4-0.8 \mathrm{~mm}, 1.3-1.5$ times as long as the posterior segment, base whitish, towards the segments apex light green. Lip tripartite, light green, base white, towards the segments apex light green; undivided basal part prominent, $1-2.8 \times 1.7-2.5 \mathrm{~mm}$; side segments linear, 7.8-8.8(-11.0) $\times 0.6-0.9(-1.0)$ $\mathrm{mm}, 1.3-1.5$ times as long as the median segment; median segment linear-ligulate, straight, 5.5-7.0 $\times$ 0.9-1.9 mm; spur slightly sinuous to hooked, sometimes projected frontwards, free from the bracts, subclavate, 1.3-2.1 times as long as the pedicellate ovary, 2.5-4.6 cm long, base 0.6-1.4 $\mathrm{mm}$ wide, whitish, apex 1.4-2.4 mm wide, green. Gynostemium erect, 2.6-2.9 $\mathrm{mm}$ high; connective emarginate, light green; auricles fleshy, verrucose, whitish, $0.6 \times 0.7 \mathrm{~mm}$, apex round- 
ed. Anther locules $1.8-2.3 \mathrm{~mm}$ high, canals short, $1.0-1.1 \mathrm{~mm}$ long, hemipollinaria separated, $3.7 \mathrm{~mm}$ long, viscidium $0.75 \times 0.6 \mathrm{~mm}$, spaced $1.4-1.6 \mathrm{~mm}$ apart, caudicles $1.3 \mathrm{~mm}$ long, pollinia $1.6 \times 1.1 \mathrm{~mm}$. Stigma lobes 2, mostly separate, in contact only at the apex, oblong, light green, flat, receptive surface turned upwards, 2.1-2.3 mm long, apex $1.2 \mathrm{~mm}$ wide, obtuse, margins not involute, space between the stigma lobes oblong to elliptic. Rostellum $3.4 \mathrm{~mm}$ long, white; midlobe triangular, fleshy, erect, obtuse, completely placed between the anther loci, $1.8 \mathrm{~mm}$ high; side-lobes parallel throughout, $1.9 \mathrm{~mm}$ long.

Distribution AND CONSERVATION STATUS: Habenaria bicornis is distributed from southern Mexico (Campeche and Veracruz), Central America (Guatemala, Honduras, and Panama), the Caribbean (Cuba), northern South America (Venezuela and Guyana), to northern (Pará), northeastern (Paraíba, Pernambuco, and Sergipe), central (Goiás, Mato Grosso, and Tocantins) and southeastern (Minas Gerais) Brazil. Although the species is widespread throughout most of the Neotropics, it is uncommon and locally known from few collections (except from Cuba, where several collections are known, particularly from the province of Pinar del Rio). Despite its low frequency, but because of its broad distribution, H. bicornis can be classified as Least Concern (LC) according to the World Conservation Union Red List Categories and Criteria (IUCN, 2001).

HABITAT, ECOLOGY AND PHENOLOgY: Habenaria bicornis is commonly found in lowland, permanently wet savannas (chagüite, matorral, selva baja caducifolia inundable, acuática, wet grassland, wet boggy meadow, sandy wet banks, moist grassy places, wet fields, campo alagado, campo úmido, pântano, brejo). The species also occasionally occurs at the interface between wet grassland and gallery forests. Elevations range from near the sea level to $800 \mathrm{~m}$, but most records $(90 \%)$ are from below $400 \mathrm{~m}$. Flowering occurs from the peak of the rainy season to its end: from February to March in central and southeastern Brazil; and from June to October in northeastern Brazil and in the northern hemisphere (Table 3). As in most species of the genus, $H$. bicornis begins a new growth cycle during the rainy season. A new vegetative shoot grows from the tuber formed during the previous season and produces a new stem, which forms a new tuber and a terminal inflorescence. After maturation of the capsules as the dry season approaches, the stem and leaves wither and are lost, and the new tuberoid becomes dormant. Because of its habitat preferences, Habenaria bicornis seems to be less affected by fire regimens than other Neotropical species of the genus from seasonal humid grasslands (Batista et al. 2003, 2010, Batista \& Bianchetti 2010), which usually depend upon fire for large-scale flowering.

Illustrations: Kränzlin (1911, table 2, fig. 2, as $H$. caldensis, based on Lindman 2791 1/2), Hoehne (1940, plate 67; figure I, as H. goyazensis, based on Pickel 3615), Snuverink \& Westra (1983: 572, fig. 3, as $H$. caldensis, based on Wilson-Browne 2), Batista et al. (2008, fig. 2K-L, as H. goyazensis, based on Batista et al. 683).

The illustration of $H$. exaltata in Flora Brasilica (Hoehne 1940, plate 68) is most probably based on Lindman 2765 (S) and referable to H. bicornis. The material illustrated in Pabst \& Dungs (1975: 250, fig. 97), and identified as H. goyazensis, is based in on Chagas s.n. - INPA 826, and is referable to $H$. longipedicellata.

Additional SPeCimens EXAmined: MEXICO. Campeche: Carretera Kalkiní-El Remate, $2 \mathrm{~km}$ antes de llegar a El

TABLE 3. Number of flowering specimens of $H$. bicornis for each of its main geographic distribution areas. The total includes all collected specimens from each region, including materials with fruits, and with or without collection dates.

\begin{tabular}{l|c|c|c|c|c|c|c|c|c|c|c|c|c}
\hline Taxa & Jan & Feb & Mar & Apr & May & Jun & Jul & Aug & Sep & Oct & Nov & Dec & Total \\
\hline Mexico and Central America & & & & & & & & 2 & 2 & 1 & & & 8 \\
\hline Cuba & & & & & & & & 8 & 4 & 2 & & & 25 \\
\hline $\begin{array}{l}\text { Northeastern Brazil and northern South } \\
\text { America }\end{array}$ & & & & & & 1 & 1 & 2 & 2 & & & & 8 \\
\hline Central and southeastern Brazil & & 4 & 1 & & & & & & & & & & 7 \\
\hline
\end{tabular}


Remate, selva baja caducifolia inundable, acuática, comum, flor verde-amarillenta, con el centro blanquecino, 11 October 1999 (fl), M. Pena-Chocarro, J. Tun, L. Salinas \& J. Hinojosa 599 (BM); Veracruz: Totutla, Mata Obscura, matorral en terreno plano, flores verdes tierno con el centro blanquecino, 30 September 1972 (fl), A.F. Ventura 7072 (EAP). CUBA. Herb. Estac. Centr. Agron. 753 (BR). Cienfuegos: Cieneguita, in wet grassy lands, not uncommon, 7 or 8 August 1895 (fl), R. Combs 440 (AMES, $\mathrm{GH}, \mathrm{MO}$ ); Cieneguita, in wet grassland and open wood land, 3 September 1895 (fl), R. Combs 755 (GH). Guantánamo: Oriente, in savanna, 2 August 1914 (fl), E.L. Ekman 2375 (NY); Bayate, Sabana Miranda, 15 September 1915 (fl), E.L. Ekman 6449 (US). Matanzas: San Miguel de los Baños, on slope of Jacán hill, Grassy place, 6 August 1919 (fl), B. León \& M. Roca 8898 (NY). Pinar del Rio: vicinity of Herradura, Royal Palm savanna, flowers greenish-yellow, 26-30 August 1910 (fl), N.L. Britton, E.G. Britton, F.S. Earle \& C.S. Gager 6337 (AMES, K, NY, US); Laguna Santa María, sandy pinelands, 8 September 1910 (fl), N.L. Britton, E.G. Britton \& C.S. Gager 7153 (AMES, NY); Vicinity of Pinar del Río, sandy wet bank, in pinelands, sepals green, 5-12 September 1910 (fr), N.L. Britton, E.G. Britton \& C.S. Gager 7247 (AMES, NY); Pinar del Río to Viñales, grassy bank, flowers greenish, 12 September 1910 (fl), N.L. Britton, E.G. Britton \& C.S. Gager 7302 (NY); north of La Guira, San Diego de los Baños, 26 August 1914 (fl), B. León 4585 (NY); Pinar del Río, Sabana de Bacunagua, October 1931 (fl, fr), B. León 15061 (US); Sumidero, Savanna del Sumidero, in campis graminosis, October 1823 (fl), Poeppig 1845 (G, W, W-R 20324); 1824 (fl), Poeppig s.n. (W); Poeppig s.n. (W-R 20323); in savannarum regionis humiden locis uliginosis,flor albo, Poeppig s.n. (W-R 20322); campi inundati, Poeppig s.n. (P 386869); North of [Consolacion] del Sur, savana, 23 August 1924 (fl), J.T. Roíg y Mesa \& M.A. Chrysler 3263 (NY); west of Guane along the Mantua road, palm barren, moist grassy places, 25 November 1911 (fr), J.A. Shafer 10480 (A, NY); Cuchillas de San Sebastian, vicinity of Sumidero, siliceous formation, grassy hillside, fls. greenish-white, 9 August 1912 (fl), J.A. Shaffer \& B. León 13714 (A, BM, NY); Cuchillas de San Sebastian, vicinity of Sumidero, top of Cuchillas, flower greenishwhite, 9 August 1912 (fl), J.A. Shaffer \& B. León 13718 (NY). Villa Clara: Santa Clara, Banks of Lagoon Haití, Mordazo, 29 December 1915 (fr), B. León \& F.R. Cazanás 5924 (NY); Santa Clara, near Manacas, 27 December 1915 (fr), B. León \& F.R. Cazanás 5966 (NY). GUATEMALA. graminosis uliginosis, August 1870 (fl), G. Bernoulli 922 (W-R). HONDURAS. Francisco Morazán: Near Las Mesas, in chagüite, common, 2 December 1950 (fr), P.C. Standley 27834 (EAP); near Las Mesas, wet boggy meadow, petals greenish-white, 30 August 1948 (fl), L.O. Williams \& A. Molina 14712 (EAP). PANAMA. Panamá: Canal Zone,
Las sabanas, fl. greenish, 10 September 1914 (fl), H.F. Pittier 6792 (US); Panama City, near Matías Hernández, wet field, common but plants all dried, 30 December 1923 (fr), P.C. Standley 28982 (US); Panama City, between Matías Hernández and Juan Diaz, 21 January 1924 (fr), P.C. Standley 32032 (US). VENEZUELA. Bolivar: Cuidad Guayana, Mission deu Caroni, Canton de Upata (?), dan les savannes humiden, 1864 (fl), Grosourdy s.n. (P 00386911); Portuguesa: Guanare, Mesa Alta (Mesa del Indio), 10 $\mathrm{km}$ al N-W de Guanare, en chaparrales associados com sabanas, flores blanco-verdosas, 94'N, 6944'W, 300 m, 19 September 1988 (fl), G. Aymard \& C. Ramirez 7067 (MO). GUYANA. Upper Takutu-Upper Esequibo: Rupununi River, savanna, August 1948 (fl), G. Wilson-Browne 2 (K, NY, RENZ). BRAZIL. Goiás: Mossâmedes, Serra Dourada, Fazenda Agua Fria, Pohl 1645 (BR, W); São Domingos, Fazenda Craibinha, cerrado, campo úmido, 16 March 2004 (fl), A.A. Santos et al. 2422 (BHCB, CEN). Minas Gerais: Ituiutaba, margens do Rio Paranaíba, Fazenda Santa Terezinha, varjão (campo alagado), fl. verde-amareladas, 18 February 1949 (fl), A. Macedo 1695 (HB). Mato Grosso: Serra das Araras, in campis, perianthum viride, 15 February 1894 (fl), C.A.M. Lindman 2765 (S); prope rivum Esmeril, in campo uliginoso graminoso, C.A.M. Lindman 2791 1/2 (S, spirit). Pará: Marajó, 1877-1878 (fl), Jobert 141 (P, RENZ). Paraíba: Remígio, terrenos alagados e encapoeirados, flores branco-creme, segmentos vegetativos verdes, 13 September 2005 (fl), L.P. Felix 10803 (EAN). Pernambuco: Tapera (S. Bento), no pântano (lagoa do cercado), flores brancoamarellas, 26 June 1934 (fl), B. Pickel 3615 (IPA, NY, SP); Lagoa do Ouro, 9'08'60"S, 35²8'60"W, 24 August 2013 (fl), L.P Felix \& E.M Almeida 14643 (EAN). Sergipe: Japaratuba, beira de rodovia pavimentada, campo limpo encharcado (brejo), ao lado de um filete d água, relevo plano, conspícuas, se destacando no campo, flores alvoesverdeadas, 23 July 2005 (fl), J.F.B. Pastore 1452 (BHCB). Tocantins: Araguaçu, 18-20 km após Araguaçu, na estrada para Alvorada, nas bordas de mata ciliar úmida com campo úmido adjacente, 16 February 1997 (fl), J.A.N. Batista et al. $683(\mathrm{CEN})$.

TAXONOMiC nOTES: Poeppig collected several specimens of $H$. bicornis in Cuba. The holotype in $\mathrm{K}$ is labeled just 'Cuba, 1822'. The collection data of the other specimens varies from 'Cuba, Savana del sumidoro, October 1823, E.F. Poeppig 1845' (G 169029, W-R 20324, W s.n.), to 'Cuba, 1824' (W s.n.) or just 'Cuba' without any date or collection number (P 386869, W-R 20322, W-R 20323). In a synopsis of New World Habenaria, Batista et al. (2011a) incorrectly cited the most complete collection data as the type data and interpreted the specimens in $\mathrm{G}$ and $\mathrm{P}$ as isotypes. 
Some authors have considered H. bidentata Poepp. ex Steud., a nomen nudum, a synonym of $H$. bicornis (Cogniaux 1909, Galé 1938). However, the name was first published by Sprengel (1826) as a synonym of $H$. alata Hook. Accordingly, there are several collections from Poeppig at W (W s.n., W-R 43241, W-R 20301, $\mathrm{W}-\mathrm{R}$ 20302) originally identified as $H$. bidentata and which are all referable to $H$. alata. Some authors have considered $H$. tricuspis a synonym of $H$. repens (Cogniaux 1909, Ames 1910, Galé 1938, León \& Schweinfurth 1946), but examinations of the type materials in $\mathrm{P}$ and $\mathrm{W}$ confirmed it as a synonym of $H$. bicornis. Habenaria radicans Griseb., from Cuba, was published as a synonym of $H$. tricuspis (Grisebach 1866), but the name is based on the specimen $C$. Wright 3309 (AMES 70164, BM 32525, K), which is H. repens. ACKNOWLEDGMENTS. The authors thank the curators and staff of the following herbaria for providing digital images or access to their collections and support during our visits: $\mathrm{A}, \mathrm{ALCB}, \mathrm{AMES}, \mathrm{B}, \mathrm{BHCB}, \mathrm{BM}$, BR, CEN, CEPEC, CESJ, CTES, EAN, EAP, ESA, G, GH, HB, HBG, HRB, HRCB, HUEFS, IBGE, ICN, IPA, K, L, LP, M, MBM, MBML, MO, NY, OUPR, OXF, P, PMSP, R, RB, RENZ, S, SI, SP, SPF, U, UB, UEC, US, W; Gustavo Romero for scanning the image of $H$. goyazensis published by Kränzlin, Adalberto José dos Santos for permission and assistance in the use of Leica M205C stereoscopic microscope, Ana Cláudia Fernandes for translation of the abstract to Spanish, and two anonymous reviewers for improvements on the manuscript. JANB acknowledges financial support from Conselho Nacional de Desenvolvimento Científico e Tecnológico (CNPq), Fundação de Amparo a Pesquisa do Estado de Minas Gerais (FAPEMIG) and a scholarship (Pq-2) from CNPq.

\section{LiterATURE CITED}

Ames, O. 1910. The genus Habenaria in North America. Orchidaceae 4: 1-288.

Ames, O. 1922. New or noteworthy orchids from different parts of the world. Orchidaceae 7: 83-140.

Ames, O. 1928. Orchidaceae. In: P.C. Standley (ed.), Flora of the Panama Canal Zone. Contributions from the United States national Herbarium. Vol. 27.

Batista, J.A.N., L.B. Bianchetti \& E.G. Gonçalves. 2003. An overlooked new species of Habenaria (Orchidaceae) from Central Brazil. Novon 13: 397-402.

Batista, J.A.N., J.B.F. Silva \& L.B. Bianchetti. 2008.
The genus Habenaria (Orchidaceae) in the Brazilian Amazon. Rev. Bras. Bot. 31: 105-134.

Batista, J.A.N. \& L.B. Bianchetti. 2010. Taxonomy, distribution and new taxa from the Habenaria crucifera (section Nudae, Orchidaceae) aggregate from Brazil and the Guianas. Brittonia 62: 57-79.

Batista, J.A.N., B.M. Carvalho, A.J. Ramalho \& L.B. Bianchetti. 2010. Three new species of Habenaria (Orchidaceae) from Serra da Canastra, Minas Gerais. Phytotaxa 13: 27-39.

Batista, J.A.N., L.B. Bianchetti, R. González-Tamayo, X.M.C. Figueroa \& P.J. Cribb. 2011a. A synopsis of new world Habenaria (Orchidaceae) I. Harvard Pap. Bot.16: 1-47.

Batista, J.A.N., L.B. Bianchetti, R. González-Tamayo, X.M.C. Figueroa \& P.J. Cribb. 2011b. A synopsis of new world Habenaria (Orchidaceae) II. Harvard Pap. Bot. 16: 233-273.

Batista, J.A.N., K.S. Borges, M.W. Faria, K. Proite, A.J. Ramalho, G.A. Salazar \& C. van den Berg. 2013. Molecular phylogenetics of the species-rich genus Habenaria (Orchidaceae) in the New World based on nuclear and plastid DNA sequences. Mol. Phylogenet. Evol. 67: 95-109.

Bonfield, J.K., K.F. Smith \& R. Staden. 1995. A new DNA sequence assembly program. Nucleic Acids Res. 24: 4992-4999.

Cabral, J.S., L.P. Felix \& M. Guerra. 2006. Heterochromatin diversity and its co-localization with $5 \mathrm{~S}$ and $45 \mathrm{~S}$ rDNA sites in chromosomes of four Maxillaria species (Orchidaceae). Genet. Mol. Biol. 29: 659-664.

Chase, M.W., R.S. Cowan, P.M. Hollingsworth, C. van den Berg, S. Madriñán, G. Petersen, O. Seberg, T. Jørgsensen, K.M. Cameron, M. Carine, N. Pedersen, T.A.J. Hedderson, F. Conrad, G.A. Salazar, J.E. Richardson, M.L. Hollingsworth, T.G. Barraclough, L. Kelly \& M. Wilkinson. 2007. A proposal for a standardised protocol to barcode all land plants. Taxon 56: 295-299.

Cogniaux, A. 1893. Orchidaceae. Habenaria. Pp. 18-102 in: C.F.P. Martius, A.G. Eichler \& I. Urban (eds.) Flora Brasiliensis 3(4). München, F. Fleischer.

Cogniaux, A. 1909. Orchidaceae VII. Habenaria. Pp. 297-309 in: I. Urban (ed.), Symbolae Antillanae seu Fundamenta Florae Indiae Occidentalis. Vol. 6. Leipzig, F. Borntraeger.

Correa, A., D. Mireya, C. Galdames \& M.N.S. Stapf. 2004. Catálogo de las Plantas Vasculares de Panamá. Smithsonian Tropical Research Institute, Panama.

D'Arcy, W.G. 1987. Flora of Panama. Check list and index. Part I: The introduction and checklist. Missouri Botanical Garden. St. Louis, Missouri.

D’Emerico, S., D. Pignone, G. Bartolo, S. Pulvirenti, C. 
Terrasi, S. Stuto \& A. Scrugli. 2005. Karyomorphology, heterochromatin patterns and evolution in the genus Ophrys (Orchidaceae). Bot. J. Linn. Soc. 148: 87-99.

Dressler, R.L. 1980. Checklist of the orchids of Panama. Monographs in Systematic Botany from the Missouri Botanical Gardens 4: 1-26.

Dressler, R.L. 1993. Field guide to the orchids of Costa Rica and Panama. New York, Cornell University Press.

Edgar R.C. 2004. MUSCLE: multiple sequence alignment with high accuracy and high throughput. Nucleic Acids Res. 32: 1792-1797.

Erixon P., B. Svennblad, T. Britton \& B. Oxelman. 2003. Reliability of Bayesian posterior probabilities and bootstrap frequencies in phylogenetics. Systematic Biol. 52: 665-673.

Felix L.P. \& M. Guerra 1998. Cytological studies on species of Habenaria Willd. (Orchidaceae-Orchidoideae) occurring in the Northeast of Brazil. Lindleyana 13: 224-230.

Felix, L.P. \& L.P. Guerra. 1999. Chromosome analysis in Psygmorchis pusilla (L.) Dodson \& Dressler: the smallest chromosome number know in Orchidaceae. Caryologia 52: 165-168.

Felix, L.P. \& L.P. Guerra. 2005. Basic chromosome numbers of terrestrial orchids. Pl. Syst. Evol. 254: 131-148.

Felsenstein J. 1985. Confidence limits on phylogenies: an approach using the bootstrap. Evolution 39: 783-791.

Fitch W.M. 1971. Toward defining the course of evolution: minimum change for a specific tree topology. Syst. Zool. 20: 406-416.

Galé, J.A. 1938. Catálogo descriptivo de las orquideas cubanas. Bol. Estac. Exp. Agron. Santiago de las Vegas. Vol. 60

Govaerts, R., P. Bernet, K. Kratochvil, G. Gerlach, G. Carr, P. Alrich, A.M. Pridgeon, J. Pfahl, M.A. Campacci, D. Holland Baptista, H. Tigges, J. Shaw, P. Cribb, A. George, K. Kreuz \& J. Wood. 2013. World Checklist of Orchidaceae. Royal Botanic Gardens, Kew. Available from: http://apps.kew.org/wcsp/ (accessed: 11 July 2013).

Grisebach, A. 1866. Catalogus plantarum cubensium. G. Engelmann, Leipzig.

Grisebach, A. 1873. Habenaria. Pp. 233 in: F.A. Sauvalle (ed.), Flora Cubana: enumeration nova plantarum cubensium. Havana, La Antilla.

Hoehne, F.C. 1940. Orchidaceas. Habenaria. Pp 52-254 in: F.C. Hoehne (ed.) Flora Brasilica 12(1). São Paulo, Secretaria da Agricultura, Indústria e Comércio de São Paulo.

Hijmans, R.J., S.E. Cameron, J.L. Parra, P.G. Jones \& A. Jarvis. 2005. Very high resolution interpolated climate surfaces for global land areas. Int. J. Climatol. 25: 1965-1978.

IUCN. 2001. IUCN Red List Categories and Criteria,
Version 3.1. IUCN Species Survival Commission, Gland.

IUCN Standards and Petitions Subcommittee. 2010. Guidelines for Using the IUCN Red List Categories and Criteria. Version 8.1. Prepared by Standards and Petitions Subcommittee in March 2010.

Kränzlin F. 1892. Beitrage zu einer monographie der gattung Habenaria Willd. Engl. Bot. Jahrb. 16: 52-223.

Kränzlin, F. 1901 Orchidacearum genera et species. Vol. I. Habenaria. Mayer \& Müller, Berlin.

Kränzlin, F. 1911. Beiträge zur orchideenflora Südamerikas. Kongl. Svenska Vetenskapsakad. Handl. 46: 1-105.

Kress W.J., L.M. Prince \& K.J. Williams. 2002. The phylogeny and a new classification of the gingers (Zingiberaceae): evidence from molecular data. Amer. J. Bot. 89: 1682-1696.

León, H. \& C. Schweinfurth. 1946. Familia 2. Orquideas. In: H. León (ed.) Flora de Cuba. Vol. 1. Contribuciones ocasionales del Museo de Historia Natural del Colegio de La Salle, 8. Habana, Cultural S.A.

Lindley, J. 1830-1840. The genera and species of orchidaceous plants. J. Ridgways, London.

Moraes, A.P., I.J. Leitch \& A.R. Leitch. 2012. Chromosome studies in Orchidaceae: karyotype divergence in Neotropical genera in subtribe Maxillariinae. Bot. J. Linn. Soc. 170: 29-39.

Nylander, J.A.A. 2004. MrModeltest v2. Program distributed by the author. Evolutionary Biology Centre, Uppsala University.

Pabst, G.F.J. \& F. Dungs. 1975. Orchidaceae Brasilienses. Vol. 1. Brucke-Verlag Kurt Schmersow, Hildesheim.

Pearson, R.G., C.J. Raxworthy, M. Nakamura \& A.T. Peterson. 2007. Predicting species' distributions from small numbers of occurrence records: a test case using cryptic geckos in Madagascar. J. Biogeog. 34: 102-117.

Phillips, S.J., R.P. Anderson \& R.E. Schapire. 2006. Maximum entropy modeling of species geographic distributions. Ecol. Model. 190: 231-259.

Pridgeon A.M., P.J. Cribb, M.W. Chase \& F.N. Rasmussen .2001. Genera orchidacearum, Vol. 2. Orchidoideae, part 1. Oxford University Press Inc, New York.

Renz, J. 1992. The genus Habenaria (Orchidaceae) in the Guianas. Candollea 47: 483-512.

Richard, A. 1850. Ophrydeae. Habenaria. Pp. 249-250 in: D. Ramon de La Sagra (ed.), Historia fisica, politica y natural de la isla de Cuba. Segunda parte. Historia Natural. Tomo XI. Botanica. Paris, A. Bertrand.

Ronquist, F., J.P. Huelsenbeck \& P. van der Mark. 2005. MrBayes: Bayesian Inference of Phylogeny. Program distributed by the authors. Available from: http:// mrbayes.sourceforge.net/index.php.

Sérgio, C., R. Figueira, D. Draper, R. Menezes \& A.J. Sousa. 2007. Modelling bryophyte distribution based 
on ecological information for extent of occurrence assessment. Biol. Conserv. 135: 341-351.

Simpson, M.G. 2006. Plant systematics. Elsevier Academic Press, Burlington, San Diego and London.

Snuverink, J.H \& L.Y. Th. Westra. 1983. Studies on the flora of the Guianas. 3. A survey of Habenaria Willd. in Suriname (Orchidaceae). Proc. Kon. Nederl. Akad. Wetensch., C, 86(4): 567-594.

Souza, L.G.R., O. Crosa, P. Speranza \& M. Guerra. 2012. Cytogenetic and molecular evidence suggest multiple origins and geographical parthenogenesis in Nothoscordum gracile (Alliaceae). Ann. Bot. 109: 987-999.

Sprengel, C.P.J. 1826. Systema vegetabilium. Editio decima sexta, vol. 3. Sumtibus Librariae Dieterichianae, Göttingae.

Stearn, W.T. 1992. Botanical Latin. 4o ed. Timber Press, Portland.

Swofford, D.L. 2002. PAUP*. Phylogenetic analysis using parsimony (*and other methods). Version 4. Sinauer Associates, Inc., Sunderland.
Sun, Y., D.Z. Skinner, G.H. Liang \& S.H. Hulbert. 1994. Phylogenetic analysis of Sorghum and related taxa using internal transcribed spacers of nuclear ribosomal DNA. Theor. Appl. Genet. 89: 26-32.

Tamura, K., J. Dudley, M. Nei \& S. Kumar. 2007. MEGA4: Molecular evolutionary genetics analysis (MEGA) software version 4.0. Mol. Biol. Evol. 24: 1596-1599.

Whitten, W.M., N.H. Williams \& M.W. Chase. 2000. Subtribal and generic relationships of Maxillarieae (Orchidaceae) with emphasis on Stanhopeinae: Combined molecular evidence. Amer. J. Bot. 87: 18421856.

Williams, L.O. 1946. Orchidaceae. Habenaria. Pp. 11-16 in: R.E. Wood \& R.W. Schery (eds.), Flora of Panana. Part. 3. fas. 2. Annals of the Missouri Botanical Garden. Vol. 33(1). Facsimile reprint (1980).

Williams, L.O. 1956. An enumeration of the Orchidaceae of Central America, British Honduras and Panama. Ceiba 5(1): 1-256.

APPENDIX. Additional specimens examined of morphological similar species.

Habenaria caldensis. BRAZIL. A. Ghillany s.n. (HB 57918), A. Glaziou 16372 (BR, P, RENZ), A. Macedo 2964 (NY, RB, US), 5206 (HB), A.C.D. Munhoz \& C.A.N. Martins 91 (BHCB), 94 (BHCB), A.C.D. Munhoz et al. 69 (BHCB), 84 (BHCB), 157 (BHCB), 165 (BHCB), A. Salino et al. 10863 (BHCB), A.B. Joly et al. 1246 (SP), 1366 (SP), A.F. Regnell III 1181 (P, S, US, W), A.J. Sampaio 6706 (BHCB, R), 6888 (SP, R), A.P. Duarte 7835 (NY, RB), B. Orssich s.n. (HB 66528), C.M. Sakuragui et al. in CFCR 15109 (SPF), D. Zappi et al. 9568 (SPF), E.N. Lughadha \& J.R. Pirani H51022 (K), E. Pereira 8903 (AMES, HB, RB), E. Simonis \& I. Cordeiro in CFCR 4098 (SPF), E.L. Borba 102 (BHCB), 107 (BHCB), E.P. Heringer \& A. Castellanos 6014 (AMES, HB), 6074 (UB), 6219 (UB), 6219-A (HB), 6228 (UB), 22243 (R), E.P. Heringer 6229 (UB), E.R. Pansarin \& A.O. Simões 786 (CEN, UEC), 803 (CEN, UEC), F.C. Hoehne s.n. (SP 4945, SPF 65025), G. Hatschbach \& Z. Ahumada 31572 (MBM), G. Hatschbach \& J. Cordeiro 51837b (MBM), G. Hatschbach et al. 28748 (HB, MBM, NY, UEC, US), 36315 (HB, MBM, NY, RENZ), 40828 (MBM), 64355 (HBG, MBM), 64355 (BHCB, MBM), G. Martinelli et al. 11343 (RB), G. Windisch 2582 (HB), G.W.A. Fernandes s.n. (BHCB 27951), H.S Irwin et al. 12406 (HB, NY), 18782 (HB, NY, UB), 19899 (AMES, HB, RB, UB), 19993 (AMES, HB, M, NY, RB,UB, US), 20869 (AMES, HB, NY, RB, UB, US), 22045 (UB), 22391 (HB, NY, UB), 22556 (HB, NY, UB), 22701 (UB), 23431 (AMES, HB, NY, RB, UB, US), 28037 (HB, UB), 32177 (NY, UB), 34025 (HB, HBG, NY,
UEC), $34025 a$ (UB), 35417 (NY), Jobert 87 (P), J. Badini s.n. (OUPR 9712, 9721, 9726), J. Semir \& A.B. Joly 3811 (SP), 3814 (SP), J. Semir \& M. Sazima 4941 (SP, UEC), J.A. Lombardi 4615 (BHCB), J.A.N. Batista 154 (CEN), 250 (CEN), 1828 (BHCB), 2621 (BHCB), 2633 (BHCB), J.A.N. Batista \& A.R.C. Lemos 1061 (CEN, UEC), J.A.N. Batista \& E.R. Pansarin 1139 (CEN), 1156 (CEN, UEC), J.A.N. Batista \& K. Proite 987 (CEN), 1021 (CEN), J.A.N. Batista \& L.B. Bianchetti 396 (CEN), 895 (CEN), 919 (CEN), J.A.N. Batista et al. 714 (CEN, MBM, SP), 1359 (CEN, SP), 1382 (CEN), 1389 (CEN), 1798 (BHCB), 1818 (BHCB), 1900 (BHCB), 1950 (BHCB), 2405 (BHCB), 2413 (BHCB), 2415 (BHCB), 2458 (BHCB), 2737 (BHCB), 2794 (BHCB), 2820 (BHCB), 2856 (BHCB), 2877 (BHCB), 2955 (BHCB), 3120 (BHCB), 3147 (BHCB), J.R. Pirani et al. 2212 (SPF), 2296 (SPF), 3963 (SPF), in CFCR 9144 (SPF), L. Damasio s.n. (OUPR 9707, 9708), L.B. Smith et al. 15958 (HB, US), L. Mickeliunas \& E.R. Pansarin 03 (CEN, UEC), 15 (CEN, UEC), 34 (CEN, UEC), L. Th. Dombrowski 7000 (MBM), L.A. Martens 255 (SPF), M. Barreto 4870 (BHCB), 4871 (BHCB, SP), 8929 (BHCB, R, SP), M. Magalhães 1100 (BHCB, SP), 1126 (BHCB), M.F.A. Calió et al. 29 (SPF), M.G.L. Wanderley et al. 577-A (SP), M.M. Arbo et al. 4629 (AMES, K), 5215 (AMES, SPF), M.S. Werneck 66 (BHCB), M. Sazima 13400 (UEC), N.L. Menezes et al. 7099 (SP), N.S. Bittencourt Jr. 00/42 (UEC), P.L. Viana s.n. (BHCB 69740), P.L. Vianna 577 (BHCB), Piliackas et al. 10907 (SPF), R. Mello-Silva et al. in CFCR 8862 (SPF), 9040 (SPF), R.C. Mota \& P.L. 
Viana 1704 (BHCB, CEN), 1711 (BHCB), R.C. Mota 1698 (BHCB, CEN), 1720 (BHCB), 1729 (CEN, BHCB), 2733 (BHCB), R.S. Oliveira 276 (CEN, UB), R.S. Oliveira et al. s.n. (UB), R.W. Windisch 2596 (HB), R.W. Windisch 491 \& A. de Ghillany (HB), S. Mayo et al. 7010-A (SP), S. Mayo et al. 7013 (SP), T.F. Daniel \& N. Hensold 2298 (SPF) 2298 A (SPF), 2315 (BHCB), 2369 (BHCB), V.C. Souza et al. 8226 (ESA), W.A. Teixeira s.n. (BHCB 26081), W.R. Anderson et al. 35415 (HB), 35417 (HB, MBM, NY, UB, US), 36098 (HB, NY, UB, US).

Habenaria exaltata. BRAZIL. Amadeu 37 (HB, ICN), E. Hassler 8721 (BM), G. Hatschbach 10946 (HB, L, MBM, U), 13773 (MBM), 15962 (HB, MBM), 18323 (MBM), G.F.J. Pabst 1318 (B, HB, HBG, K, RB, S), J. Dutra 1074 (ICN, SI, SP), J. Klein 149 (BHCB), J.A.N. Batista et al. 2771 (BHCB), 2520 (BHCB), 2798 (BHCB), J.L. Waechter 1976 (ICN), L. Arzivenco 521 (ICN), M. Emmerich 3174 (HB, R), M. Pedron 6 (ICN), P. Jorgensen 4646 (US), 4648 (S, SI), P.K.H. Dusen 3272 (R, SP, SPF), Z.A. Trinta 1204 (HB, HBG, K, L, LP, M).

Habenaria rodeiensis. BRAZIL. A.A. Vale et al. 133 (BHCB), A. de Saint-Hilaire B1 854 (P), B2 2201 (P), A. Krapovickas \& C. L. Cristóbal 33555 (CTES), A. Ruschi 52 (SP), A.C. Brade 10657 (SP), 11367 (R), 12541 (RB), s.n. (R 28922, RB 53103), C. Spannagel 228 (SP), C.M. Izumisawa et al.
167 (PMSP), C.N. de Fraga 609 (MBML), D. Sucre 2522 \& Braga 363 (RB), D. Sucre 2292 (NY, RB, US), E.P. Heringer et al. 6332 (IBGE, K), 11078 (HB), 16824 (HB), 18146-A (IBGE), 18201 (IBGE), E.R. Pansarin \& L. Mickeliunas 1015 (BHCB, UEC), E. Ule 4006 (HBG), F.C. Hoehne 241 (SP), F.H. Caetano s.n. (HRCB), F.R. Nonato 994 (HUEFS), G. Edwall in CGGSP 3670 (SP), G. Hatschbach 1211 (MBM), G. Hatschbach et al. 13451 (MBM), G.F.J. Pabst 690 (HB), 928 (HB, NY), 937 (HB, NY), 938 (HB, K), 947 (HB), 964 (HB), 6822 (HB), 7323 (HB), G.J. Shepherd et al. 7451 (UEC), H. Schenck 2346 (BR), J. Vidal 89 (R), J.A.N. Batista 1419 (CEN), J.A.N. Batista et al. 77 (CEN), 1471 (CEN), 1472 (CEN), J.A.N. Batista \& T.R. Peixoto 3273 (BHCB), J.A. Jesus \& T.S. Santos 404 (CEPEC), Kuhlmann 6010 (RB), L. Kollmann 86 (MBML), 2732 (MBML), 2733 (MBML), L. Kollmann \& R.R. Veruloet 2826 (MBML), L. Kollmann et al. 2526 (MBML), L.H. Bailey \& E.Z. Bailey 1110 (AMES), M. Mattos s.n. (R 28932, 28954), N.L. Abreu et al. 143 (CESJ), O. Handro 2033 (SPF), 2085 (SPF), P. Martuscelli 101 (SP), R. Kautsky 88 (HB), 591 (HB), R.C. Mota 2824 (BHCB), R.F. Campos s.n. (SP 28922), R.M. Valadão et al. 67 (ALCB), S.A. Mori et al. 10045 (CEPEC), S. Lima \& A.C. Brade 14322 (RB), T. Konno et al. 763 (SP), T. Jost et al. 364 (HRB), V.C. Souza et al. 3651 (ESA), W. Boone 366 (MBML), 533 (MBML). 